\title{
MODEL PENGAJARAN AGAMA ISLAM DI UNIVERSITAS SUMATERA UTARA (USU) MEDAN
}

\author{
Teaching Model of Islamic Religion \\ at University of North Sumatra (USU), Medan
}

\author{
Imran Siregar \\ Puslitbang Pendidikan Agama dan Keagamaan \\ Badan Litbang dan Diklat Kementerian Agama RI \\ Jl. M.H. Thamrin No.6 lt.18 Jakarta Pusat \\ Email:imran.siregar56@yahoo.com
}

Naskah diterima tanggal 3 Februari 2014. Naskah direvisi tanggal 5 Maret 2014. Naskah disetujui tanggal 3 April 2014

\begin{abstract}
Abstrak
Praktik pengajaran PAI di USU memunculkan keanekaragaman komentar baik dari pimpinan Perguruan Tinggi Umum (PTU) maupun mahasiswa. Model konvensional pengajaran agama, yaitu model ceramah dan tanya jawab, dimana peran dosen lebih dominan dibandingkan dengan peran mahasiswa membuat mahasiswa mencari alternatif pendidikan agama di luar kegiatan intra kampus. Model pengajaran dan materi kajian agama kompetitor di luar intra kampus tersebut lebih "seksi" dan mengundang perhatian mahasiswa dibandingkan dengan materi yang disampaikan dosen PAI di ruang kuliah. Memperkokoh penyelenggaraan MPK sebagai pengembangan dari mata kuliah agama di PTU dan penguatan kompetensi akademik serta kedudukan dosen PAI yang simpatik dan kompetitif adalah sebuah keniscayaan.
\end{abstract}

Kata kunci: PTU, pendidikan agama Islam, pengajaran.

\begin{abstract}
Practically, the teaching of Islamic religion at University of North Sumatra issues various comments both from the leaders of public university and from the students. The conventional model of teaching religion is lecturing model and asking questions model in which the lecture's role is more dominant than the students. Consequently, they found the alternative education to learn religion lessons outside campus. The teaching model and the materials of religion lessons outside campus are more interesting to be learnt than Islamic religion taught by the lecturers at the campus. It is necessary to strengthen the implementation of personal development course as the expansion of religion course at public university and to strengthen the academic competence, and the position of the lecturers who are congenial and competitive.
\end{abstract}

Keywords: public university, islamic education, teaching.

\section{PENDAHULUAN}

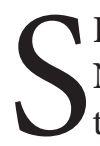

$\mathrm{K} \quad$ Mendiknas No.045/U/2002 terjadi Perguruan Tinggi Umum. Dalam SK tersebut ditegaskan bahwa Pendidikan Agama tidak masuk dalam materi mata kuliah tersendiri melainkan menjadi salah satu mata kuliah dalam kelompok MPK (Mata Kuliah Pengembangan Kepribadian).
Dalam kurikulum yang direstrukturisasi tersebut dipergunakan pendekatan baru yang dikenal dengan Kurikulum Berbasis Kompetensi yang sangat mengutamakan kompetensi setiap mata kuliah, dimana materi pengajaran keagamaan di PTU lebih mengedepankan aspek kompetensi tertentu ketimbang sebuah pengetahuan dan pemahaman.

Rambu-rambu pelaksanaan MPK ini tercantum dalam SK No.43/DIKTI/Kep. 2006, khususnya menegaskan tentang rumusan visi, misi, 
standar kompetensi, dan kompetensi dasar. Visi dan misi MPK memberi penekanan kepada pemantapan kepribadian mahasiswa sebagai manusia Indonesia seutuhnya, yang secara konsisten mampu mewujudkan nilai-nilai dasar keagamaan dan kebudayaan. Kompetensi dasar Pendidikan Agama adalah menjadi ilmuwan; (i) professional, (ii) beriman dan bertaqwa kepada Tuhan Yang Maha Esa, (iii) berakhlak mulia, (iv) memiliki etos kerja, (v) berkepribadian dewasa, menjunjung tinggi nilainilai kemanusiaan dan kehidupan. Hal ini berarti fokus pada internalisasi nilai dan perbedaan teologis dan perbedaan madzhab dalam masalah fiqihiyah tidak menjadi materi utama dalam pengajaran PAI di PTU.

Dalam UU No. 20 tahun 2003 tentang Sistem Pendidikan Nasional (Sisdiknas) secara tegas menyatakan hak setiap peserta didik mendapatkan pendidikan agama. Dalam Bab V Pasal 12 ayat 1 point a menegaskan bahwa setiap peserta didik berhak untuk mendapatkan pendidikan agama sesuai agama yang dianutnya dan diajarkan oleh pendidik yang seagama. Hal ini berarti setiap peserta didik pada semua jalur dan jenjang pendidikan, baik tingkat dasar, menengah maupun tinggi, berhak untuk mendapatkan pendidikan agama sesuai agama yang dianut dan diajarkan oleh guru agama yang seagama dengan peserta didik.

Pendidikan agama yang dimaksudkan UU tersebut, sebagaimana tercantum dalam ketentuan umum PP No. 55 tahun 2007 pada pasal 1 ayat 1 adalah sebuah pendidikan yang memberikan pengetahuan dan membentuk sikap, kepribadian dan keterampilan peserta didik dalam mengamalkan ajaran agamanya yang dilaksanakan sekurang kurangnya melalui mata pelajaran/kuliah pada semua jalur, jenjang dan jenis pendidikan. Hal ini berarti bahwa pendidikan agama merupakan mata kuliah tersendiri, tidak digabungkan dengan mata pelajaran/mata kuliah lainnya pada semua jenjang pendidikan, termasuk pada bangku kuliah.

Adapun fungsi dari pendidikan agama adalah membentuk manusia Indonesia yang beriman dan bertakwa kepada Tuhan Yang Maha Esa, serta berakhlak mulia dan mampu menjaga kedamaian dan kerukunan hubungan intern dan antar umat beragama. Sedangkan tujuan pendidikan agama adalah untuk berkembangnya kemampuan peserta didik dalam memahami, menghayati, dan mengamalkan nilai- nilai agama yang menyerasikan penguasaannya dalam pengembangan ilmu pengetahuan, seni dan teknologi (PP. No.55 tahun 2007 pasal 2 ayat 1 dan 2). Penanggungjawab pendidikan agama pada semua jalur dan jenjang pendidikan adalah Menteri Agama (Pasal 3 ayat 2).

Kedua kebijakan tersebut (Menteri Pendidikan dan Menteri Agama) memiliki kesamaan tujuan. Meskipun tidak memasukkan materi pendidikan agama dalam mata kuliah tersendiri, akan tetapi dalam Mata kuliah Pengembangan Kepribadian (MPK) secara eksplisit kompetensi dan tujuan yang diharapkan dari pendidikan agama tidak sekedar menjadikan agama sebagai pengetahuan, tapi juga menjadikan agama sebagai sumber etos kerja dan etos sosial, sama-sama membentuk manusia yang beriman dan bertakwa. Intinya agama dipahami tidak hanya sebagai pengetahuan tapi juga harus mencerminkan perilaku baik secara individu maupun secara sosial.

Meski demikian, dalam implementasinya, kompetensi yang ingin dicapai dalam pendidikan keagamaan tersebut, sulit untuk terealisasi. Ada beberapa hal yang menyebabkan tidak tercapainya kompetensi tersebut, antara lain; (a) jumlah sks untuk mata kuliah agama yang sangat terbatas, (b) model pengajaran PAI yang lebih cenderung dogmatif, tidak kritis, lebih bersifat monolog doktriner, dan hampir tidak ada perdebatan adu gagasan, (c) materi pengajaran PAI yang kurang memadai, (d) dan dosen yang kurang kompeten.

Akibatnya para mahasiswa mencari dan mendapatkan pemahaman keagamaan di luar kampus. Mereka memperoleh pengetahuan dan pemahaman keagamaan dari kelompok kelompok kajian Islam di luar pembelajaran PAI di kampus. Kelompok-kelompok kajian Islam tersebut lebih "seksi" dan menawarkan banyak warna dan pendekatan dalam pemahaman keagamaan Islam, mulai yang sifatnya tekstual normatif, hingga yang kontekstual liberal. Perbedaan pendekatan tersebut menjadi alasan mahasiswa mencari alternatif PAI di luar PAI yang terjadwal di kampus.

Berdasarkan latar belakang tersebut di atas rumusan masalah penelitian ini difokuskan pada 3 (tiga) hal, yaitu: 1) menganalisis model pengajaran PAI di USU; 2) menganalisis sistem evaluasi pengajaran PAI; dan 3) menganalisis mekanisme dan sistem rekrutmen dosen PAI di USU.

Hasil studi ini ditujukan kepada para pengambil kebijakan (Kemenag dan Kemdikbud) terkait pembenahan pengajaran PAI di PTU, khususnya di USU. 


\section{METODE PENELITIAN}

Pendekatan penelitian ini adalah pendekatan kualitatif, kasus pengajaran PAI di USU. Peneliti menjadi instrumen utama dalam penggalian data dan informasi. Untuk mendapatkan data dan informasi yang lebih mendalam dilakukan melalui FGD, wawancara dan studi dokumen yang berkaitan dengan profil dosen, sistem dan pola pengajaran serta evaluasi pengajaran agama,dan mekanisme rekrutmen dosen agama. Proses penelitian berlangsung selama lima bulan (JuliNopember) pada tahun anggaran 2013. Lokus studi di Universitas Sumatera Utara (USU) Medan.

Data yang diperoleh dianalisis dengan mengaitkan antar data berdasarkan hasil wawancara mendalam (FGD) dan studi dokumen tentang kebijakan pendidikan agama, proses pengajaran PAI dan rekrutmen dosen.

\section{Sekilas USU}

Sejarah Universitas Sumatera Utara (USU) dimulai dengan berdirinya Yayasan Universitas Sumatera Utara pada tanggal 4 Juni 1952. Pendirian yayasan ini dipelopori oleh Gubernur Sumatera Utara dengan maksud untuk memenuhi keinginan masyarakat Sumatera Utara khususnya dan masyarakat Indonesia umumnya.

Diawali tanggal 20 Agustus 1952 saat didirikan Fakultas Kedokteran di Jalan Seram dengan dua puluh tujuh orang mahasiswa dan kemudian hari momen tersebut ditetapkan sebagai hari jadi atau Dies Natalis USU yang diperingati setiap tahun. Kemudian disusul dengan berdirinya Fakultas Hukum dan Pengetahuan Masyarakat (1954), Fakultas Keguruan dan Ilmu Pendidikan (1956), dan Fakultas Pertanian (1956). Pada tanggal 20 November 1957, USU diresmikan oleh Presiden Republik Indonesia Dr. Ir. Soekarno menjadi universitas negeri yang ketujuh di Indonesia.

Pada tahun 1959, dibuka Fakultas Teknik di Medan dan Fakultas Ekonomi di Kutaradja (Banda Aceh) yang diresmikan secara meriah oleh Presiden R.I. Kemudian disusul berdirinya Fakultas Kedokteran Hewan dan Peternakan (1960) di Banda Aceh. Sehingga pada waktu itu, USU terdiri dari lima fakultas di Medan dan dua fakultas di Banda Aceh.

Selanjutnya menyusul berdirinya Fakultas Kedokteran Gigi (1961), Fakultas Sastra (1965), Fakultas Matematika dan Ilmu Pengetahuan Alam (1965), Fakultas Ilmu-ilmu Sosial dan Ilmu Politik (1982), Sekolah Pascasarjana (1992), Fakultas
Kesehatan Masyarakat (1993), Fakultas Farmasi (2007), Fakultas Psikologi (2008), dan Fakultas Keperawatan (2009).

Pada tahun 2003, USU berubah status dari suatu perguruan tinggi negeri (PTN) menjadi suatu perguruan tinggi Badan Hukum Milik Negara (BHMN). Perubahan status USU dari PTN menjadi BMHN merupakan yang kelima di Indonesia. Sebelumnya telah berubah status UI, UGM, ITB dan IPB pada tahun 2000. Setelah USU disusul perubahan status UPI (2004) dan UNAIR (2006).

Dalam perkembangannya, beberapa fakultas di lingkungan USU telah menjadi embrio berdirinya tiga perguruan tinggi negeri baru, yaitu Universitas Syiah Kuala di Banda Aceh, yang embrionya adalah Fakultas Ekonomi dan Fakultas Kedokteran Hewan dan Peternakan USU di Banda Aceh. Kemudian disusul berdirinya Institut Keguruan dan Ilmu Pendidikan (IKIP) Negeri Medan (1964), yang sekarang berubah menjadi Universitas Negeri Medan (UNIMED) yang embrionya adalah Fakultas Keguruan dan Ilmu Pendidikan USU. Setelah itu, berdiri Politeknik Negeri Medan (1999), yang semula adalah Politeknik USU.

Hingga kini, USU memiliki 14 Fakultas dan sekolah pascasarjana, 47 program studi sarjana S-1, enam program pendidikan profesi, 38 program magister, 22 program Doktor dan 22 program pendidikan spesialis serta 15 program diploma III dan satu diploma IV dengan jumlah total mahasiswa USU yang terdaftar hingga Agustus 2012 sebanyak 44.030 orang, 1000 di antaranya adalah mahasiswa asing.

Proses pendidikan dan penelitian melibatkan 1.632 orang dosen, $81 \%$ di antaranya memiliki latar belakang pendidikan pascasarjana. Sementara dosen agama Islam terdiri dari 3 orang dosen tetap USU, 4 orang dosen DPK IAIN Sumut dan 3 orang dosen honorer dalam koordinasi LIDA. Jumlah alumni USU saat ini USU lebih dari 103.000 alumni yang tersebar di seluruh pelosok tanah air. Sejumlah alumni menempati posisi penting di berbagai sektor kerja, baik pemerintahan maupun swasta.

Di lingkungan dalam kampus juga terdapat berbagai sarana seperti asrama, mesjid, arena olah raga, wisma, kafetaria, toko, bank, dan kantor pos. Wisuda dan berbagai acara akademik lainnya diadakan di Auditorium dan Gelanggang Mahasiswa. Sebuah rumah sakit pendidikan yang berlokasi di kampus Padang Bulan.

Kampus utama USU berlokasi di Keluarahan Padang Bulan Kecamatan Medan Baru. Kampus ini 
memiliki luas sekitar $122 \mathrm{Ha}$, dengan zona akademik seluas sekitar 100 Ha yang berada di tengahnya.

Jarak kampus Padang Bulan dengan bandara Kualanamu Internasional Airport sekitar $38 \mathrm{~km}$ yang dapat ditempuh dengan menggunakan taksi 90 menit atau KA selama sekitar 45 menit.

Perkembangan jumlah mahasiswa USU menuntut perluasan kampus Padang Bulan dengan pengembangan Kampus Kwala Bekala. Kampus Kwala Bekala dikembangkan sebagai kampus yang humanis (nyaman, aman dan menyenangkan, berskala pejalan kaki), hemat energi, sehat dan ramah lingkungan, serta mencerminkan visi USU sebagai "U for I" (University for Industry).

Sementara misi USU adalah: 1) Mempersiapkan mahasiswa menjadi anggota masyarakat akademik dan profesional dalam menerapkan, mengembangkan pengetahuan ilmiah, teknologi dan seni, serta berdaya saing tinggi; 2) Memperluas partisipasi dalam pembelajaran untuk memenuhi kebutuhan nasional dalam pembelajaran dan modernisasi cara pembelajaran; dan 3) Mengembangkan dan menyebarluaskan pengetahuan ilmiah, teknologi, seni, dan rancangan penerapannya untuk mendukung produktivitas dan daya saing masyarakat.

\section{PEMBAHASAN}

\section{Status Mata Kuliah PAI}

Mata kuliah PAI di USU masih menjadi mata kuliah yang berdiri sendiri dan belum menjadi bagian dari Mata Kuliah Pengembangan Kepribadian (MPK) sebagaimana diamanatkan dalam Surat Keputusan (SK) Menteri Pendidikan Nasional No. 232/U/2000 dan No. 45/U/2002. Sampai saat ini alokasi untuk mata kuliah agama di PTU adalah 2 SKS. Minimnya SKS ini membuat para dosen kesulitan untuk menerapkan MPK sehingga masih terus menjadikan PAI sebagai matakuliah tersendiri. Pengalaman para dosen, 2 SKS dirasa sebagai alokasi yang minimal. Menurut Ibu Zakiyah, mereka sudah pernah mengajukan kepada pihak kampus untuk menambahan menjadi 3 SKS, namun hingga penelitian ini dilakukan permintaan tersebut tidak disetujui. Para dosen beranggapan bahwa penambahan 1 SKS akan sangat membantu dalam proses pembelajaran khususnya untuk alokasi praktik dalam rangka membangun dan membentuk sikap dan karakter peserta didik sebagaimana telah dirumuskan dalam kompetensi mata kuliah (tujuan instruksional umum): "Pendidikan Agama di Perguruan Tinggi
Umum bertujuan untuk membantu terbinanya mahasiswa yang beriman dan bertaqwa kepada Tuhan Yang Maha Esa, berbudi pekerti yang luhur, berfikir filosofis, bersikap rasional dan dinamis, berpandangan luas, ikut serta dalam kerja sama antar umat beragama dalam rangka pengembangan dan pemanfaatn ilmu dan teknologi serta untuk kepentingan manusia dan nasional."

Pada sisi lain, Pembantu Rektor I (PR I) beranggapan bahwa mata kuliah agama justru seharusnya non SKS. Ekstrimnya lagi, kalau perlu PAI tidak lagi diajarkan di perguruan tinggi kecuali di perguruan tinggi agama seperti IAIN atau UIN. Karena menurutnya, pendidikan agama tidak bisa dipelajari dalam waktu yang singkat hanya satu semester. Pendidikan agama bukanlah pendidikan instan. Ia merupakan pendidikan yang bersifat proses mulai dari aspek teoritis sampai keaspek praktikal, dari kognisi sampai ke afeksi dan psikomotorik. Agama tidak hanya terkait dengan pengetahuan teoritis belaka. Lebih dari itu tujuan mata kuliah ini (pengajaran agama) bukanlah sekedar mengalihkan pengetahuan dan keterampilan (sebagai isi pendidikan), melainkan lebih merupakan upaya menggugah fitrah kemanusiaan sehingga mahasiswa bisa menjadi penganut agama yang taat dan baik.

Selanjutnya ditegaskan, bahwa PAI bukan merupakan kegiatan yang terpisah dari aspekaspek kehidupan masyarakat luas yang berlangsung dalam konteks keselarasan maupun keseimbangan dengan kegiatan-kegiatan, baik perorangan maupun kelembagaan dan dalam posisi yang saling memperkokoh atau memperkuat antara yang satu dengan yang lain. Kampus hanya menjadi salah satu konstributor untuk membangun manusia yang dewasa dalam berpikir dan berperilaku. Di luar kampus banyak pihak yang tidak kalah penting peranannya, yang turut memberikan konstribusi pelaksanaan pendidikan agama. Maka dengan demikian keterlibatan pranata sosial kemasyarakatan yang lain turut serta memberikan andil bagi keberhasilan pendidikan agama baik dari sisi kuantitas maupun kualitas.

Dari sinilah PR I mewakili pihak kampus mempertanyakan bagaimana mungkin mata kuliah agama dengan karakter yang demikian dapat diberi nilai dengan angka. Apakah nilai yang diberikan oleh seorang dosen PAI dapat mencerminkan keberagamaan mahasiswa? Apakah nilai A mahasiswa dalam mata kuliah PAI dapat memastikan cerminan bahwa sang mahasiswa memiliki tingkat keberagamaan yang tinggi dan bagus sesuai dengan nilai yang diperolehnya? 
Dua sudut pandang yang berbeda ini berakibat pada praktik pelaksanaan perkuliahan PAI. Perkuliahan yang seharusnya mendapatkan porsi ideal sesuai harapan para dosen justru terlaksana dalam posisi dan kondisi yang tak seharusnya. Pertama, perkuliahan harus dilakukan dalam kelas besar dengan jumlah mahasiswa di atas 50 (lima puluh) bahkan ada yang sampai 120 (seratus dua puluh). Kedua, kondisi ini diperparah dengan kurang memadainya dukungan sistem tata suara dalam ruang kuliah (sound system) di beberapa fakultas. Hal ini berakibat pada proses perkuliahan PAI yang kurang efektif dan menjurus ke arah sia-sia. Untuk sebuah perkuliahan, satu kelas diisi lebih dari 30 peserta didik saja sudah kurang efektif dan dosen akan menemui kesulitan menguasai kelas besar atau forum. Pengawasan dosen terhadap aktivitas belajar mahasiswa di kelas tidak bisa menyeluruh terlebih lagi dengan keterbatasan tata suara dalam ruangan. Maka bila kondisi ini ditambah dengan tidak adanya sistem tata suara, misalnya speaker, sudah bisa dipastikan bahwa proses perkuliahan tidak dapat terlaksana dengan baik dan maksimal.

Hal tersebut diakui sendiri oleh koordinator dosen PAI, Dra. Zakiah, M.Pd. Menurutnya, dalam kondisi tersebut di atas dosen akan kesulitan menguasai seluruh kelas. Dosen tidak bisa mengenal mahasiswa dengan baik. Saat mengajar di dalam kelas dosen juga tidak bisa mengontrol perilaku mahasiswa apalagi yang duduk atau berada di posisi belakang. Bukannya mengikuti perkuliahan, ia justru asyik bermain dengan handphone-nya. Kenyataan ini berujung pada prinsip para dosen "yang penting mengajar, terserah mahasiswa mau mendengar atau tidak".

Fasilitas sarana perkuliahan yang disediakan oleh masing-masing fakultas berbeda antara satu fakultas dengan fakultas lainnya sesuai dengan kemampuan finansial yang ada. Misalnya di FISIP susah sekali kalau mau memakai infocus karena jumlahnya sangat terbatas. Sementara di Fakultas Kedokteran dan Ilmu Komputer Teknologi Informasi fasilitas sangat mencukupi, infocus tersedia di setiap kelas. Sangat berbeda dengan fakultas lainnya, pengeras suara tidak tersedia sementara perkuliahan PAI dilaksanakan dengan kelas besar. Semua ini terkendala oleh masalah pendanaan, baik untuk menyediakan fasilitas yang memadai maupun menggaji dosen. Karenanya untuk dibagi menjadi kelas-kelas kecil pun tidak memungkinkan. Di samping karena masalah pendanaan, ruang kelas pun diakui tidak mencukupi.

\section{Proses Pengajaran PAI}

Pengajaran PAI memiliki acuan utama yang dinamakan Garis-garis Besar Program Pengajaran (GBPP). GBPP kemudian dikembangkan menjadi Satuan Acara Pembelajaran (SAP). Materi pembelajaran terbagi menjadi dua, yaitu materi pokok sesuai dengan GBPP dan materi pokok yang disesuaikan dengan disiplin ilmu masingmasing mahasiswa. Materi kategori pertama memiliki kompetensi khusus sebagaimana dirumuskan di dalam GBPP yaitu: kemampuan memahami dan menjelaskan berbagai konsep ketuhanan, membuktikan eksistensi Tuhan dan menunjukkan kekhasan serta kebenaran dalam Islam; kemampuan memahami dan menjelaskan makna, karakter orang beriman, korelasi iman dan taqwa, serta terbentuknya iman dan taqwa yang intens; kemampuan memahami dan menjelaskan berbagai persoalan dalam kehidupan modern, serta menawarkan problem solving yang islami; kemampuan memahami dan menjelaskan hakikat manusia, posisi manusia di hadapan Allah serta bersikap sebagai makhluk bermartabat; kemampuan memahami dan menjelaskan konsep hukum, hak asasi manusia (HAM), dan demokrasi dalam perspektif Islam; kemampuan memahami dan menjelaskan sumber hukum Islam, fungsi hukum Islam, serta menunjukkan kontribusi muslim dan hukum Islam dalam sistem Hukum Nasional; kemampuan memahami dan menjelaskan makna etika, moral dan akhlak, menunjukkan kekhasan akhlak dan hubungannya dengan tasawuf, serta terbentuknya akhlak mulia sebagai anggota masyarakat; kemampuan memahami dan menjelaskan konsep Islam tentang ilmu pengetahuan dan teknologi (Iptek), serta kemampuan bersikap sebagai ilmuwan/akademis yang bertanggung jawab; kemampuan memahami dan menjelaskan makna Islam sebagai ramatan lil álamin, serta terbentuknya sikap solidaritas yang proporsional dalam kehidupan bersama umat agama lain; kemampuan memahami dan menjelaskan konsep masyarakat madani, serta menunjukkan peran muslim sebagai terbentuknya masyarakat madani dan kesejahteraan umat; kemampuan memahami dan menjelaskan konsep ekonomi Islam, serta menunjukkan kemungkinannya bagi upaya pengingkatan kesejahteraan umat; kemampuan memahami dan menjelaskan konsep, karakteristik, dan dinamika kebudayaan Islam; kemampuan memahami dan menjelaskan konsep politik dalam perspektif Islam, serta peran muslim dalam politik nasional. 
Sementara itu materi pokok yang disesuaikan dengan disiplin ilmu mahasiswa disesuaikan dengan di fakultas apa mahasiswa belajar. Oleh karena itu, setiap fakultas memiliki penekanan tema yang disesuaikan dengan kompetensi masing-masing fakultas. Misalnya, PAI di Fakultas Kedokteran akan membahas etika kedokteran dalam Islam sementara di fakultas lain tidak membahasnya. Demikian pula misalnya di Fakultas Ekonomi yang lebih mengembangkan pembahasan tentang ekonomi Islam. Titik tekan materi yang berbeda-beda dan khas bagi masing-masing fakultas ini menjadi tema perkuliahan yang diberikan kepada para mahasiswa di akhir pertemuan dalam satu semester.

Model pengajaran yang dipakai oleh para dosen PAI dalam perkuliahan tidak jauh berbeda dengan model yang dipraktikkan oleh para narasumber dalam seminar. Tahap pertama lebih banyak dilakukan dengan pemaparan oleh dosen dengan ceramah dan atau bila memungkinkan dosen memberikan presentasi lewat infocus. Tahap selanjutnya dosen memberikan kesempatan kepada mahasiswa untuk bertanya dan dosen menjawab. Tanya jawab antara dosen dan mahasiswa tak jarang berujung pada diskusi. Pengambilan metode perkuliahan yang demikian tak lepas dari kompetensi khusus dan capaiannya yang melulu menyentuh ranah kognitif. Tak mengherankan bila di dalam SAP yang mereka susun hanya menyertakan metode kuliah mimbar, diskusi, dan jigsaw. Walaupun demikian, harus pula diingat bahwa kesinambungan pendidikan agama tidak terletak pada banyak ataupun tingginya materi yang disajikan, apalagi alokasinya yang sangat terbatas, yaitu 2 SKS dalam satu semester. Maka masalah metodologi dalam hal penguasaan teori dan praktik tentang cara pendekatan yang tepat dan cermat guna mencapai tujuan menjadi faktor yang sangat menentukan.

Di samping itu, mayoritas dosen juga mewajibkan kepada para mahasiswi untuk mengenakan jilbab saat perkuliahan. Peraturan ini bukan peraturan resmi pihak kampus dan bukan pula kesepakatan semua dosen PAI. Walaupun ada juga dosen yang membebaskan mahasiswinya dari berjilbab, tetap saja muncul kesan umum bahwa perkuliahan PAI merupakan kawasan wajib berjilbab. Menurut pengakuan dosen, kewajiban ini memiliki pengaruh positif dalam perkembangan keagamaan para mahasiswi. Beberapa justru dengan sukarela terus memakai jilbab dalam kehidupan sehari-hari sebagaimana diakui oleh mahasiswinya.
Karena PAI masuk dalam struktur Mata Kuliah Umum (MKU), maka di USU PAI masuk dalam koordinasi LIDA (Laboratorium Ilmu Dasar dan Ilmu Umum). Untuk pelaksanaan perkuliahan PAI diserahkan kepada Dra. Zakiah, M.Pd. untuk mengkoordinasikan para dosen PAI. Koordinasi tidak hanya mengumpulkan para dosen dan membagi kelas-kelas yang wajib diampuh oleh dosen tertentu, namun juga mengatur GBPP dan SAP perkuliahan agar tidak keluar dari acuan. Memang tidak ada rapat khusus untuk dosen PAI di setiap awal semester dalam rangka membahas dan menentukan proses perkuliahan untuk satu semester ke depan. Semua urusan kelas diserahkan kepada dosen kecuali materi baku yang tercantum di GBPP. LIDA sendiri tidak membakukan pemahaman apa yang harus diajarkan kepada para mahasiswa karena dalam anggapannya para dosen PAI yang di bawah naungan LIDA tidak menunjukkan indikasi terinfiltrasi oleh pemahaman-pemahaman radikal maupun transnasional yang bisa mengikis moderasi Islam.

Walaupun proses perkuliahan di kelas diserahkan kepada dosen masing-masing, untuk lebih menyamakan acuan mereka menggunakan satu buku acuan utama. Sampai saat ini buku acuan utama yang masih mereka gunakan adalah terbitan resmi dari Direktorat Pendidikan Tinggi Islam, Direktorat Jenderal Pendidikan Islam, Departemen Agama (kini menjadi Kementerian Agama) Jakarta pada tahun 2009. Buku tersebut berjudul "Pengembangan Kepribadian Pendidikan Agama Islam pada Perguruan Tinggi Umum" yang disusun oleh Prof. Dr. M. Abduh Malik, Prof. Dr. Uswatun Hasanah, Drs. Mujilan, M.Ag., dan Dr. Nurwahidin, M.Ag. Untuk materi pertemuan akhir yang disesuaikan dengan disiplin ilmu masingmasing tidak ada dalam buku tersebut. Selain buku induk ini, untuk pengembangan para dosen dibebaskan untuk mengambil dari buku-buku lain yang berkaitan dengan tema-tema yang diajarkan. Saat ini mereka sedang menyusun buku ajar Pendidikan Agama Islam yang kini dalam tahap revisi dan ditargetkan selesai pasca lebaran $1434 \mathrm{H}$. Menurut Dra. Zakiah, M.Pd, revisi ini terkait dengan penambahan atas materi-materi yang disesuaikan dengan disiplin ilmu mahasiswa. Jadi pembahasanpembahasan khas perfakultas akan memiliki acuan yang pasti dan jelas.

Dalam proses perkuliahan, kontrol dari mahasiswa juga cukup baik walaupun terkadang ada sedikit penentangan dari dosen. Suatu kali ada 
mahasiswa dari Fakultas Tehnik mengadukan dosen PAI-nya kepada Pembantu Dekan I. Menurutnya dosen pengampuh tidak mengajar sesuai dengan GBPP dan SAP yang disepakati. Padahal GBPP dan SAP bersifat terbuka dan selalu disampaikan kepada para mahasiswa di awal pertemuan perkuliahan sehingga mahasiswa telah mengikuti gambaran tentang materi yang akan diterimanya selama satu semester. Dosen tersebut dalam pandangan mahasiswa mengajar di kelas sesukanya saja. Akibatnya, di semester tahun depan dosen yang bersangkutan tidak diberi lagi jam mengajar di Fakultas Tehnik. Ia pun melapor kepada koordinator dosen PAI di LIDA. Konflik pun mengemuka manakala aduan mahasiswa dikonfirmasikan kepada dosen terkait. Dosen yang bersangkutan tidak mau menerima tuduhan tersebut dan mengelak bahwa itu hanya laporan mahasiswa saja tanpa dipertanyakan lebih lanjut pada dirinya.

Tentunya kejadian seperti ini tidak akan terjadi bila tidak ada api yang mengasapi. Memang banyak kemungkinan, namun laporan seperti ini menunjukkan bahwa transparansi dalam proses perkuliahan sangat penting dan diperlukan. Kesepakatan dalam bentuk kontrak belajar di awal perkuliahan menjadi starting point perkuliahan untuk pertemuan-pertemuan selanjutnya. Mahasiswa tetap berhak untuk tahu apa yang akan diperolehnya selama satu semester dan dosen perlu untuk membimbing sesuai jalur kesepakatan. Tanpa ada kontrak belajar, niscaya situasi dan proses perkuliahan akan buta serta tanpa arah. Apalagi bilamana kemudian ditemukan adanya ajaran-ajaran yang menjurus pada pengabsahan tindakan kekerasan bahkan cenderung radikal, mahasiswa dapat memberikan kontrol. Tidak ada pihak lain yang dapat memberikan kontrol terbaik kecuali mahasiswa yang jelas-jelas mengikuti proses perkuliahan. Walaupun memang sampai saat ini belum ada laporan kepada pihak terkait mengenai transformasi paham keagamaan yang mengarah kepada kekerasan bahkan radikal atau mungkin paham yang dianggap sesat, tetap hal ini perlu diwaspadai.

Dalam konteks ini pelaksanaan perkuliahan PAI di perguruan tinggi juga memerlukan suasana interaksi antara dosen dan peserta didik yang lebih intens. Figur dosen agama Islam tidak sekedar sebagai pengampuh dan penyampai materi kuliah tetapi lebih dari itu ia adalah sumber inspirasi "spiritual" sekaligus pembimbing sehingga terjalin hubungan pribadi antara dosen dan peserta didik yang cukup dekat dan mampu melahirkan perpaduan bimbingan antara rohani dan akhlak dengan materi pembelajarannya. Sampai di sini fungsi dan peran dosen PAI tidak melulu hanya bermodalkan profesionalitas sesuai undang-undang guru dan dosen yang mencakup kompetensi kepribadian, pedagogik, sosial dan professional, namun juga perlu didukung oleh kekuatan moral atau akhlak.

Proses perkuliahan PAI di USU terbagi dalam dua model kelas. USU mengadakan kelas simultan dan kelas reguler untuk mata kuliah PAI. Kelas simultan mirip dengan model semester pendek yang biasanya diikuti oleh sedikit mahasiswa. Sementara kelas reguler merupakan kelas dengan perkuliahan yang diselenggarakan selama satu semester penuh. PAI untuk kelas reguler ini diberikan di semester pertama. Hanya di Fakultas Ilmu Sosial dan Ilmu Politik serta Faultas Teknologi Informasi yang diberikan di semester kedua. Kelas reguler inilah yang biasanya diselenggarakan dalam format kelas besar dengan banyak mahasiswa.

Kalau 13 (tiga belas) materi ajar di atas diperhatikan, mulai dari materi konsep ketuhanan dalam Islam sampai dengan materi sistem politik Islam, hakekatnya tidak menutup kemungkinan bagi dosen untuk membuka peluang masuk ke ranah afektif ataupun psikomotorik. Capaian komptensi untuk membangun dan menumbuhkan kesadaran tentang pluralitas kehidupan beragama memang sudah sangat pas. Apalagi untuk masa sekarang di mana kesadaran untuk menghormati perbedaan sedikit demi sedikit makin luntur, materi kerukunan umat beragama memang sudah selayaknya menyentuh perasaan, emosi, sistem nilai, dan sikap hati (attitude). Tujuannya tidak hanya memahami dan menganalisis namun lebih dari itu, yaitu memperhatikan fenomena sampai dengan yang kompleks yang merupakan faktor internal seseorang, seperti kepribadian dan hati nurani. Sikap hati, sikap menghargai, serta kecenderungan emosi harus ditumbuhkan.

Sebenarnya tidak hanya materi kerukunan antar umat beragama yang bisa menyentuh ranah afektif. Banyak materi PAI yang seharusnya juga dapat memasuki capaian kompetensi afektif. Realitas inilah yang memicu Pembantu Rektor I USU mengeluarkan pernyataan dan sikap sebagaimana tersebut di atas. Pertama, kritik terhadap posisi pengajaran PAI yang dirasa tidak perlu lagi diajarkan di perguruan tinggi umum. Kedua, salah satu alasannya adalah sistem 
penilaian PAI yang belum juga menemukan format idealnya. Pernyataan prihatin yang senada juga disampaikan oleh Direktur Jenderal Pendidikan Islam, Prof. Dr. H. Mohammad Ali, MA. dalam sambutannya untuk buku materi pembelajaran mata kuliah PAI. Menurutnya, di mana relevansi kebenaran dan kehebatan ajaran Islam jika tidak mampu mempengaruhi pemeluknya? Ini salah satu problem yang dikemukakannya yang sekaligus menjadi tantangan bagi para dosen. Problemnya ini diakibatkan antara lain oleh adanya orientasi pendidikan agama yang kurang tepat atau bahkan keliru. Ia menyebutkan 3 (tiga) indikator kekeliruan, yaitu: a) Pendidikan agama saat ini lebih berorientasi pada belajar tentang ilmu agama. Karenanya tidak aneh bila di negeri ini sering kita saksikan seseorang yang banyak mengetahui nilai-nilai ajaran agama tapi perilakunya tidak mencerminkan nilai-nilai ajaran agama yang diketahuinya. b) Tidak memiliki strategi penyusunan dan pemilihan materi-materi pendidikan agama sehingga sering tidak ditemukan hal-hal yang prinsipil yang seharusnya dipelajari dari awal, malah terlewatkan. Kekacauan materi pendidikan agama ini terlebih jelas lagi terlihat pada pemilihan disiplin ilmu fikih yang dianggapnya sebagai puncak atau inti agama itu sendiri. c) Kurangnya penjelasan yang luas dan mendalam serta kurangnya penguasaan semantik dan generik atas istilah-istilah kunci dan pokok dalam ajaran agama sehingga sering ditemukan penjelasan yang sudah sangat jauh dan berbeda dari makna, spirit dan konteksnya.

Mempertimbangkan fakta kondisi ini wajar bila kemudian para dosen PAI mengajukan penambahan SKS untuk melengkapi SKS yang sudah ada. Namun, apakah dengan penambahan SKS bisa menjamin perubahan proses perkuliahan PAI dari yang sudah dilakukan selama ini? Inilah yang menjadi pertanyaan Pembantu Rektor I yang juga seharusnya dijawab dengan hasil riil oleh para dosen PAI.

Kendala lain dalam praktiknya, tuntutan pelaksanaan perkuliahan PAI cenderung lebih banyak menguras dari sisi pengajaran atau didaktik metodiknya. Dosen menjadi disibukkan dengan persoalan proses belajar-mengajar dan tenggelam dalam persoalan teknis-mekanis. Sementara persoalan yang lebih mendasar yang terkait dengan aspek pedagogiknya kurang banyak disentuh sementara fungsi utama PAI di perguruan tinggi umum adalah memberikan landasan yang mampu menggugah kesadaran dan mendorong peserta didik melakukan perbuatan yang mendukung pembentukan pribadi muslim yang kuat dan taat. Dalam memberikan landasan itu tidak cukup hanya dilihat dari persoalan pengajaran atau didaktik metodiknya melainkan harus masuk ke dalam persoalan pedagogiknya juga.

Untuk menyiasatinya agar tidak hanya teori yang diberikan kepada mahasiswa namun juga praktik, beberapa dosen PAI pun mengadakan simulasi dalam proses perkuliahan dan mentoring. Simulasi biasanya terkait dengan materi perkuliahan yang membutuhkan praktik ibadah langsung, misalnya menjadibilal jenazah. Sementara mentoring diselenggarakan dengan memberdayakan mushalla yang berada di lingkungan kampus. Mahasiswa diwajibkan mengikuti mentoring di bawah arahan dan bimbingan kakak kelas yang sudah terpilih. Mereka tetap di bawah pengawasan dosen agar tidak lari ke arah aliran tertentu. Hasil dari mentoring diberikan kepada dosen dan dianggap sebagai tugas.

\section{Kajian Agama non-Mata Kuliah}

Di samping mentoring yang resmi diadakan atas permintaan dosen, ada pula kajian-kajian yang diselenggarakan oleh kelompok-kelompok tertentu, misalnya Jamaah Tabligh dan Salafi. Untuk Jamaah Tabligh, para dosen merasakan tidak ada masalah. Namun mereka kurang menyadari bahwa Jamaah Tabligh bukanlah Salafi demikian pula sebaliknya. Selama ini yang mereka temui adalah pengajian Jamaah Tabligh. Secara fisik mereka kurang bisa dibedakan, namun secara prinsipil ajaran-ajaran dan nilai-nilai keagamaan keduanya berbeda. Beberapa pengajian Salafi yang diselenggarakan di USU antara lain: Kajian Adab dan Akhlaq. Pengajian ini dilaksanakan tiap Senin pukul 10.00 WIB yang diasuh oleh Ust. Muhammad Yunus dan bertempat di Musholla Fakultas Sastra. Kajian Shahih Fiqih Sunnah. Pengajian ini diselenggarakan tiap Sabtu pukul 14.00 WIB yang diasuh oleh Ust. Abu Ihsan Al-Atsari dan bertempat di Musholla Fakultas Tehnik. Kajian Prinsip-prinsip Dakwah Salafiyyah. Pengajian ini dilakukan tiap Sabtu pukul 16.30 WIB bersama Ust. Ali Nur yang bertempat di Masjid Dakwah Pintu Tiga USU.

Selayaknya para dosen PAI di USU lebih menyadari bahwa Salafi sudah menginfiltrasi USU. Kelompok yang terkenal dengan ajaran puritanisasi ini terbukti berhasil mengadakan pengajian-pengajiannya di kompleks kampus baik di masjid maupun mushalla. Bagaimana mereka berhasil melakukan kaderisasi di USU tergambar 
dari pengakuan salah seorang anggotanya yang merupakan mahasiswa Ekstensi S1 Manajemen di Fakultas Ekonomi. Ia mengaku mengenal manhaj Salafi atau mereka biasa menyebutnya Ahlus Sunnah Wal Jamaah sejak akhir tahun 2006 dari temanteman (ia menyebutnya ikhwan) Salafi di Fakultas Ekonomi. Bahkan ia bertekad untuk istiqamah dengan manhaj Salafi yang dianggapnya sebagai manhaj yang haq (benar) hingga nafas terakhirnya berhembus. Tekad ini selaras dengan klaim kebenaran Salafi yang merasa paling benar sendiri dan di beberapa tempat menimbulkan konflik. Ideologi pembid'ahan merasuk dan seringkali merusak tatanan sosial keagamaan yang telah ada. Walaupun hal ini termasuk hak mereka untuk mengajarkan dan mengamalkan ajarannya, namun bila hal tersebut justru kontra produktif dengan nilai-nilai kebersamaan dan toleransi maka sudah selayaknya diwaspadai, dicermati, dan diarahkan.

Kompetensi khusus sebagaimana terumuskan di dalam GBPP dapat menunjukkan target perkuliahan yang diinginkan oleh para dosen. Ketika GBPP dikembangkan menjadi SAP juga tidak ada perubahan yang terlalu signifikan kecuali ada beberapa bagian materi yang menuntut adanya aktivitas analisis. Hanya satu kompetensi yang memiliki capaian menumbuhkan kesadaran, yaitu materi tentang kerukunan umat beragama. Sesuai taksonomi Bloom, kata-kata memahami, menjelaskan, dan menganalisa termasuk dalam taksonomi tujuan kognitif. Penggunaan kata-kata ini semakin menunjukkan bahwa perkuliahan PAIlebih menekankan aspek kognitif daripada afektif maupun psikomotorik. Maka wajar bila metode perkuliahan yang digunakan lebih pada ceramah ditambah dengan tanya jawab dan diskusi baik antara dosen dengan mahasiswa maupun antar sesama mahasiswa itu sendiri. Para dosen beralasan bahwa, model tersebut yang paling memungkinkan dilakukan dengan mempertimbangkan berbagai keterbatasan pengajaran PAI. Di antara keterbatasannya: alokasi waktu yang tersedia, jumlah mahasiswa dalam ruang besar, sarana ruangan yang kurang memadai, dan kurangnya dukungan dari pihak pimpinan.

\section{Evaluasi Sistem Pengajaran PAI}

Evaluasi merupakan proses yang menentukan sejauhmana tujuan pendidikan telah tercapai. Evaluasi menjadi ajang penilaian tidak hanya bagi mahasiswa, namun juga dosen terhadap keberhasilan proses belajar-mengajar yang telah berangsung. Dikatakan juga bagi dosen karena dari evaluasilah bisa diperhatikan dan diketahui apakah proses pembelajaran yang disampaikannya sampai ke mahasiswa ataukah tidak, metode yang dipakai sudah tepat ataukah tidak, dan sebagainya. Mengingat signifikansinya, maka evaluasi pembelajaran harus memakai penelitian yang sistematik dan teratur tentang manfaat atau guna pembelajaran itu sendiri. Oleh karena itu, yang dimaksud dengan evaluasi dalam pembelajaran PAI adalah keinginan untuk mengetahui, memahami, dan menggunakan hasil kegiatan belajar siswa dalam mencapai tujuan yang telah ditetapkan.

Dari SAP yang ada, evaluasi yang secara baku dipergunakan oleh para dosen PAI di USU adalah evaluasi lisan, evaluasi tulisan, performance, dan penugasan. Tidak semua model evaluasi ini digunakan oleh semua dosen. Yang paling biasa digunakan adalah evaluasi tulisan dan penugasan termasuk saat mentoring. Evaluasi secara bertahap terdiri dari evaluasi reguler yang terdiri dari keaktifan dan penugasan, Ujian Tengah Semester (UTS), dan Ujian Akhir Semester (UAS). Nilai keaktifan adalah nilai yang diperoleh dari academic record selama proses perkuliahan berlangsung. Nilai penugasan diperoleh dari berbagai macam tugas yang diberikan oleh dosen kepada mahasiswa termasuk pekerjaan rumah, kuis, maupun mentoring. Nilai UTS adalah nilai yang didapat mahasiswa saat mengikuti ujian yang dilaksanakan di pertengahan seluruh pertemuan yang harus dijalani. Sementara NUA merupakan nilai yang diperoleh dari hasil mengikuti ujian yang dilaksanakan di akhir semester. Hasil penilaian akhir sendiri diperoleh dari persentase masing-masing tahapan evaluasi tersebut. Tidak ada penyeragaman persentase penilaian. Dosen diberikan kebebasan untuk menentukan berapa persentasenya.

Untuk pembuatan soal sebenarnya LIDA telah mengupayakan adanya penyeragaman evaluasi pengajaran yang disesuaikan dengan GBPP. Bila memungkinkan akan ada soal untuk UTS maupun UAS yang dibuat bersama untuk kemudian didistribusikan oleh pihak fakultas untuk diujikan kepada mahasiswa. Walaupun demikian LIDA juga tidak menutup kemungkinan bagi dosen-dosen yang ingin membuat soal sendiri. Dalam tataran ini tentunya kontrol menjadi urgen. Karenanya LIDA tidak sekedar membebaskan namun juga memberikan aturan dan arahan kepada dosen tersebut agar dalam pembuatan dan penyusunan soal dosen pengampuh tidak keluar dari GBPP dan disesuaikan dengan kompetensi yang diharapkan dapat dicapai oleh mahasiswa. 
Evaluasi sangat diperlukan dalam rangka perbaikan di masa mendatang. Tanpa evaluasi, perbaikan tidak mungkin bisa diketahui. Karenanya setiap orang atau instansi yang bertanggung jawab atas pendidikan wajib mengadakan evaluasi termasuk dosen itu sendiri maupun pihak fakultas atau LIDA. Sampai sekarang belum ada evaluasi obyektif dari mahasiswa kepada dosen. Sebenarnya hal ini sangat penting untuk memperbaiki proses belajar-mengajar ditambah dengan itikad baik dari instansi terkait untuk melakukan perubahan. Evaluasi bisa dilakukan dengan menyebarkan angket untuk menanyakan kinerja dosen dalam mengajar, misalnya kedisiplinan, penguasaan materi, metode penyampaian, dan sebagainya. Dari sini akan dapat diperoleh lubang yang harus diperbaiki, tentunya di samping dosen itu sendiri juga perlu untuk mengevaluasi kegiatan mengajarnya sendiri. Menilai dan mengeritik diri sendiri merupakan sikap obyektif, kerendahan hati, dan keterbukaan untuk melihat dan mengakui kesalahan sendiri agar ada usaha untuk mencari cara-cara yang lain yang mungkin lebih berhasil.

Sebagaimana telah dikemukakan di bagian sebelumnya bahwa pola pengajaran yang terus memusatkan pada ranah kognitif berakibat pada evaluasi yang pada akhirnya hanya sampai pula di domain kognitif. Evaluasi lebih berorientasi pada sejauh mana mahasiswa mampu mengingat atau menghafal sejumlah materi yang telah disampaikan oleh dosen. Sementara domain afektif apalagi psikomotorik lepas dari proses evaluasi. Ini sekali lagi membuktikan bahwa proses perkuliahan hanya mengejar penumpukan materi dan informasi yang biasa dikenal dengan model bank education atau pendidikan gaya bank.

Anggapan Pembantu Rektor I tentang validitas penilaian PAI, maka hakikatnya pencapaian prestasi mahasiswa tidak dapat begitu saja diukur lewat tabel-tabel statistik. Mutu dan keberhasilan pendidikan agama Islam harus dapat diukur dengan totalitas peserta didik sebagai pribadi. Perilaku dan kesalehan yang ditampilkan dalam keseharian lebih penting dibandingkan dengan pencapaian nilai A. Maka menurut Malik Fadjar, mutu maupun pencapaian pendidikan agama perlu diorientasikan kepada: tercapainya sasaran kualitas pribadi, baik sebagai muslim maupun sebagai manusia Indonesia yang ciri-cirinya dijadikan tujuan pendidikan nasional; integrasi pendidikan agama Islam dengan keseluruhan proses maupun institusi pendidikan yang lain; tercapainya internalisasi nilai-nilai dan norma-norma keagamaan yang fungsional secara moral untuk mengembangkan keseluruhan sistem sosial budaya; penyadaran pribadi akan tuntutan hari depannya dan transformasi sosial budaya yang terus berlangsung; dan pembentukan wilayah ijtihadiyah (intelektual) di samping penyerapan ajaran secara aktif.

Tentu saja penilaian model statistik ini ada plus minusnya. Pengukuran hasilnya tampak sangat transparan dan obyektif, namun di sisi lain sebagaimana dijelaskan di atas sebagai mata kuliah agama maka spektrumnya harus lebih diperluas. Apalagi standar penilaian masing-masing dosen terkadang juga berbeda. Permasalahan seperti inilah yang sering memunculkan kerisauan di kalangan mahasiswa. Kenyataan ini membuat mahasiswa memberikan cap dosen "killer" bagi dosen yang susah dan "pelit" dalam memberikan nilai. Imbasnya, mahasiswa merasa berat untuk mengikuti perkuliahan yang diampu oleh dosen dengan cap seperti ini. Kasus seperti ini juga sempat terjadi di USU. Parahnya lagi, mahasiswa tidak lagi mengambil mata kuliah PAI, namun menyeberang ke mata kuliah agama lain yang dianggapnya mudah memberikan nilai. Nilai PAI bagaimanapun juga berpengaruh pada IPK mahasiswa yang bilamana ia memperoleh nilai jelek dalam mata kuliah PAI juga akan memperjelek IPK-nya. Bagi mahasiswa yang terpenting adalah perolehan nilainya. Ia menyatakan tidak berpindah agama dengan mengikuti mata kuliah selain agama Islam. Ia hanya berpindah mata kuliah. Tentu saja hal ini patut disayangkan karena perpindahan hanya dikarenakan nilai.

\section{Sistem Rekruitmen Dosen PAI}

Rekruitmen dosen PAI menjadi gerbang awal dimulainya pengajaran agama. Lewat rekuritmen yang tepat akan ditemukan dosen yang mampu dan qualified sesuai dengan kebutuhan pengajaran PAI. Proses rekruitmen akan selalu menyertakan mekanisme diikuti dengan syarat-syarat tertentu. Hal ini untuk menjamin keberlangsungan proses pembelajaran yang sesuai dengan apa yang diharapkan.

Proses rekruitmen dosen PAI di USU tergolong masih sangat sederhana. Ada dua macam pola rekruitmen dosen yang berjalan selama ini, yaitu lewat ujian penerimaan calon dosen Pegawai Negeri Sipil (CPNS) formasi dosen agama dan lewat jalur pertemanan dan perkenalan yang biasanya terjadi pada dosen-dosen honorer. Pola pertama menuntut persyaratan dan kriteria yang biasa diturutkan 
dalam tes atau uji penerimaan calon dosen PNS, misalnya latar belakang yang harus sesuai dengan kebutuhan. Maka dalam konteks dosen PAI, yang dibutuhkan adalah mereka yang lulus dari institusi pendidikan agama Islam seperti UIN, IAIN, STAIN, dan institusi pendidikan agama Islam swasta. Syarat lain yang kini diterapkan adalah berpendidikan minimal S2. Berhubung dosen-dosen PNS yang kini mengajar berasal dari generasi lama, maka saat itu masih bisa menggunakan ijazah S1, misalnya Dra. Zakiah, M.Pd. yang masuk menjadi PNS di USU lewat ujian masuk PNS dengan ijazah S1. Bahkan sebelumnya ia tidak mengajar terlebih dahulu di USU. Namun karena lulus ujian PNS, ia langsung mendapatkan penempatan di USU. Sementara itu untuk dosen honorer juga diperlakukan sama, yaitu berlatar belakang sesuai dengan mata kuliah PAI.

Seluruh koordinasi dosen dan pembelajaran PAI di USU berada di bawah LIDA. Berdasarkan statusnya, mereka terbagi dalam 4 (empat) kategori, yaitu: 1) Dosen Tetap adalah dosen PNS di USU yang tersebar di beberapa fakultas, yaitu dua orang dosen berasal dari Fakultas Hukum, sementara seorang dosen berasal dari Fakultas Ilmu Sosial dan Ilmu Politik (FISIP); 2) Dosen DPK dari IAIN Sumatera Utara, sebanyak empat orang; 3) Dosen Honorer adalah dosen non PNS yang turut mengajar di USU sebanyak tiga orang berada dalam kordinasi LIDA, dan ada pula yang tidak dalam kordinasi LIDA, karena langsung di bawah naungan fakultas. Kelompok kedua inilah yang sulit dikontrol oleh pihak LIDA mulai dari jadwal, materi dan cara pembelajaran, serta evaluasinya. Mereka bisa mengajar di USU karena faktor kedekatan dengan pimpinan. Di samping itu ada juga dosen yang karena kesibukannya mempercayakan pengajarannya kepada asisten dosen yang masih honorer. Mereka langsung di bawah koordinasi dosen yang diwakilinya sehingga kontrol terhadap proses pembelajaran masih bisa dilakukan oleh LIDA.

Sistem rekrutmen yeng telah berjalan selama ini dan koordinasi yang tidak maksimal telah memperkuat adanya kenyataan bahwa proses pengajaran agama Islam di USU baru sebatas karena adanya keharusan menyelenggarakan pendidikan agama bagi mahasiswa di Perguruan Tinggi. Hingga penelitian ini dilakukan pelaksanaan kewajiban tersebut belum dikelola secara maksimal sehingga menyentuh pada aspek-aspek yang menjadi kompetensi dasar yang dituntut oleh kebijakan pemerintah terkait pendidikan agama di Perguruan Tinggi.

\section{PENUTUP}

Dari uraian di atas ada beberapa hal yang dapat disarikan yaitu, pengajaran PAI di USU belum dapat memenuhi harapan stakeholder, baik kalangan PTU sendiri maupun masyarakat pada umumnya. Pengajaran PAI yang telah berjalan baru sebatas pemenuhan kewajiban memenuhi tuntutan undang-undang penyelenggaraan pendidikan agama di PTU.

Pada prakteknya pengajaran PAI tersebut memunculkan keanekaragaman komentar baik dari pimpinan PTU maupun kalangan mahasiswa yang kemudian berakibat pada makin lemahnya posisi mata kuliah tersebut. Ketika keanekaragaman komentar dan pendapat tersebut makin mengelompok maka muncullah berbagai langkah mencari alternatif lain di luar kegiatan intra kampus.

Realitas di USU para dosen PAI berhadapan dengan model pengajaran kompetitor dari luar kampus yang kemudian diidolakan oleh sebagian mahasiswa. Dikesankan, model pengajaran dan materi kajian competitor tersebut lebih "seksi" dan mengundang perhatian mahasiswa dibandingkan dengan materi yang disampaikan dosen PAI di ruang kuliah. Secara umum pengajaran PAI di USU berjalan sesuai dengan GBPP sebagai acuan utama dan dikoordinir oleh LIDA. Meskipun realitasnya belum seluruh dosen dapat dikoordinir oleh LIDA, tetap saja ada dosen yang tidak bisa terkontrol oleh LIDA khususnya mereka yang berstatus dosen honorer.

Dari tiga belas materi ajar yang ada dalam GBPP, sejatinya perkuliahan Pendidikan Agama Islam tidak hanya dalam ranah kognitif saja, namun lebih dari itu bisa menyentuh ranah afektif dan psikomotorik. Tetapi hal itu belum menunjukkan hasil, karena penilaian mata kuliah ini masih berbasis kognitif dan tidak mewakili karakter dan perilaku mahasiswa itu sendiri.

Materi pengajaran PAI terbagi menjadi dua kelompok materi, yaitu materi pokok yang sesuai dengan GBPP dan materi yang disesuaikan dengan kompetensi dan disiplin ilmu masingmasing fakultas dan jurusan/program studi. Model pengajaran agama yang dikembangkan adalah model konvensional, yaitu model ceramah dan tanya jawab, dimana peran dosen lebih dominan dibandingkan dengan peran mahasiswa.

\section{UCAPAN TERIMA KASIH}

Keberadaan Tulisan tidak terlepas dari masukan berbagai pihak. Untuk itu penulis hatur 
terima kasih kepada Rektor USU berserta jajaran, Dosen pengampuh mata kuliah Pendidikan Agama Islam dan informan lainnya yang tidak dapat penulis sebutkan. Semoga tulisan ini bermanfaat bagi perkembangan pembelajaran Pendidikan Agama Islam di masa yang akan datang.

\section{DAFTAR PUSTAKA}

Abdullah, M. 2006. Amin, Faham Keagamaan dan Faham Kebangsaan di atas Keberagamaan yang Majemuk dan Mulitkultural, Makalah disampaikan dalam Stadium General "Membangun Semangat dan Faham Kebangsaan Indonesia Di atas Keberagamaan yang Majemuk dan Multikultural", Aula Lt.5, Gedung Rektorat, Kampus C. UNAIR, 28 Juni 2006.

Abdullah, M. Amin. 2006. Islam Studies di Perguruan Tinggi : Pendekatan IntegratifInterkonektif. Yogyakarta: Pustaka Pelajar.

Abu Zaid, Nasr Hamid. 2003. Al-Qur' an, Hermenutik dan Kekuasaan. terj. Dede Iswadi.Yogyakarta: RqiS.
Achmad Munjid. 2014. Pengajaran Agama Interreligius, Kompas Sabtu, 4 Januari 2014.

Bleicher, Josef. 1980. Contemporary Hermeneutics. London: Rautledge \& Kegan Paul.

Kholidah, Lilik Nur. 2010. Implementasi Strategi Pembelajaran Mata Kuliah Pendidikan Agama Islam pada Perguruan Tinggi Negeri di Surabaya, Disertasi. Universitas Negeri Malang.

Mulyono, Pudji. 2007. Kelompok Keagamaan Di Kampus Perguruan Tinggi Umum: Sebuah Kajian Sosiologis, Mimbar Jurnal Agama dan Budaya, Vol. 24 No. 4.

Murdiono, Mukhammad. t.th. Strategi Internalisasi Nilai Moral Religius Dalam Proses Pembelajaran di Perguruan Tinggi, Jurnal Cakrawal Pendidikan. LPM UNY.

Rahman, Fazlur. 1985. Islam dan Modernitas, terj. Ahsin Muhammad. Bandung: Pustaka.

Sachedina, Abdulaziz. 2006. The Role of Islam in Public Square: Guidance or Governance?. Leiden: Amsterdam University Press. 